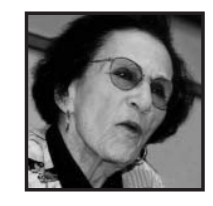

\title{
Commentary:
}

\section{Education and the Arts: The Windows of Imagination}

\author{
Maxine Greene, Columbia University
}

\section{ABSTRACT}

This article focuses upon the significance of art experiences at moments of pervasive unease and uncertainty in the society surrounding the schools. Concerned more with a loss of expectation and a sense of futility than actual fear of catastrophe, I turn towards encounters with the several arts to activate imagination which, as Emily Dickinson wrote, may "light the slow fuse of possibility." The sense of possibility, of what might be, what ought to be, what is not yet--seems to be essential in moving the young to learn to learn. It may be nurtured, not only through art education as ordinarily understood, but also through aesthetic education, moving people by means of participation, to awaken to the wonders of authentic appreciation.

begin with a poem, In Those Years by Adrienne Rich (1995), because it suggests, as prose cannot, the climate that has given rise to an argument for the arts in education. Moreover, the reader who can activate her/his imagination may be able to participate in the reality the poem creates--the isolation, the separateness, the unexpected descent of catastrophe--and experience the poem from within... 
In these

years, people will say, we lost track

of the meaning of we, of you

we found ourselves

reduced to $I$

and the whole thing became

silly, ironic, terrible;

we were trying to lead a personal life

and, yes, that was the only life

we could bear witness to

But the great dark birds of history screamed and plunged into our personal weather

They were headed somewhere else but their beaks and pinions drove along the shore, through the rags of fog

where we stood, saying I

How can we commit ourselves to learning in times like these? How, in good faith, can we enable others to learn in the shadow of those dark birds? To open spaces for learning is to give learners a sense of absence, of open questions lacking answers, of darkness unexplained. If people respond to all of this with a blank disinterest, they are, often without realizing it, acquiescing in the "given," the fixed, the unchangeable. They may have given up their "personal weather" and simply bowed to what is "natural," to what is given.

Beginning to take for granted the existing state of things--the wars, the inequities, the depth of abandoned people's suffering--they may accept the idea of there being an objective reality impervious to subjective interpretations and to alternative possibilities. Caught in a chill autonomy, they are excluded from the kind of dialogue that brings human beings in touch with one another and opens the way to the making of meanings.

It is as if they were enclosed in a silent and windowless room, unable to look at things as if they could be otherwise than they seem inescapably to be. Imagination is required to disclose a different state of things, to open the windows of consciousness to what might be, what ought to be. Imagination allows for empathy, for a tuning in to another's feelings, for new beginnings in transactions with the world. 
Crafting a poem, Dickinson (1924) wrote, "Imagination lights the slow fuse of possibility." The philosopher Ricoeur (1973) saw it as "a passion for possibility." In a way, imagination makes visible what is just out of sight. The painter Cezanne (1994) said that, although we can see the front of a painting with our eyes, imagination curves to the other side. We know that imagination makes metaphors, effecting often unexpected connections in experience. When Stevens' (1997) Man with the Blue Guitar is told, "You do not play things as they are," and he replies, "Things are changed upon the blue guitar," we know well that the guitar does not have the power to make a physical difference or actually to change things. But to bring together the color blue, a guitarist, a guitar, and images of change is to increase the resonance of particulars. Creating new patterns in experience, it somehow expands the field of meanings; it may be received as a work of art.

To think of art and education is, as I view things, to render palpable an atmosphere that offers diverse works of art for participation by students of a range of ages. I speak of participatory experiences because I hope teachers can learn what it means to attend, truly to attend to Manet's Luncheon on the Grass, in all its detail, the changing contours and hues of Monet's Rouen Cathedral at different times of day, Cezanne's House of the Hanged Man, Picasso's Guernica with its searing images of pain. I hope more teachers can share with their students glimpses of reality long obscured by familiarity, melodies long muffled by conventional tunes, cinematic scenes identified as photographic representations of the commonsense world lacking fictionality, avoiding the transformations that might change the ordinary into art. The arts, wrote Dewey (1934), "touch the deeper levels of life" (p. 46). Again, they transform; they renew. Sartre (2000), providing one of his own metaphors for imagination, wrote of pathways out of the ordinary, pathways to what might be. And he said that all human beings, for all their differences in perspective, perceive things against the background of a shared, common world. And then:

If a painter presents us with a field or a vase of flowers, his paintings are windows which are open to the whole world. We follow the red path which is buried among the wheat much farther than Van Gogh painted it among other wheat fields, under other clouds, to the river which empties into the sea, and we extend to infinity, to the other end of the world, the deep finality which supports the existence of the field and the earth. So that, through the various objects which it produces...the creative act aims at a total renewal of the world. (p. 272) 
Again, speaking of engagement, I think of the way we are in the world, acting upon it and being acted upon, always open to possibilities, to pathways seen and unseen. We are entangled with one another and, in our doing and undergoing with the world around. To grasp that, to realize that standing — unengaged-bleakly on a beach saying "I" is a denial of our humanity and of the mysterious potential in the arts.

The poet, Mary Oliver, wrote a brief essay in her book, Blue Iris, which certainly does not deal directly with art and education. Indirect as it may be, metaphorical as it may be, offering no final answers to our questions, I choose to end my foray into new landscapes with some of Oliver's words:

Teach the children. We don't matter so much, but children do. Show them daisies and the pale hepatica. Teach them the taste of sassafras and wintergreen. The lives of the blue quarters, blueberries. And the aromatic onesrosemary, oregano. Give them peppermints to put in their pockets when they go to school. Give them the fields and the woods and the possibility of the world salvaged from the lords of profit. Stand them in the stream, head them upstream, rejoice as they learn to love this green space they live in, its sticks and leaves and then the silent beautiful blossoms.... Attention is the beginning of devotion. (pp.55-56)

Urban young people, suburban young people---attention may be modeled and even taught; but devotion goes beyond words. It may be where the arts in education find their culmination-among "the silent beautiful blossoms," where the young ones can stand together, arms linked under the dark birds, imagining what might be, acting upon their vision as they begin working to renew.

\section{References}

Cezanne, P. (1994). Cezanne by himself. R. Kendell (Ed.). Boston, MA: Little, Brown.

Dewey, J. (1934). Having an Experience. In Art as Experience, 36-59. New York: Perigree. Reprinted in 2005.

Dickinson, E. (1924). The gleam of an heroic act, Part Five: The single hound, XXVII. In Complete Poems. Boston, MA: Little, Brown. Reprinted in 2002 by Bartleby.
Oliver, M. (2004). Blue iris: Poems and essays. Boston, MA: Beacon Press.

Rich, A. (1995). In those years. In Dark Fields of the Republic: Poems, 1991-1995 (p. 4). NewYork: W.W. Norton.

Ricoeur, P. (1973). The conflict of interpretations: Essays in hermeneutics. D. Ihde (Ed.). Stony Brook: State University of New York Press. 
Sartre, J.P. (2000). Basic Writings. S. Priest (Ed.). London, UK: Routledge.
Stevens, W. (1997). The man with the blue guitar. In W. Stevens, F. Kermonde, \& J. Richardson (Eds.), Wallace Stevens: Collected Poetry and Prose (pp. 135-151). New York: Literacy Classics of the United States.

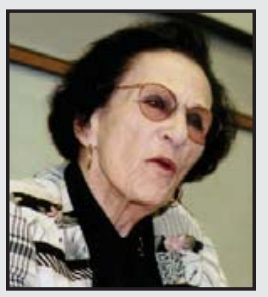

Maxine Greene received her doctorate in education from New York University in 1955. She taught at New York University, Montclair State College, and Brooklyn College. In 1965, she joined the faculty at Teachers College, Columbia University, and is currently the William F. Russell Professor in the Foundations of Education (emerita) of that institution. In 2003, she founded the Maxine Greene Foundation for Social Imagination, the Arts, and Education. A year later, the Teachers College Trustees created the Maxine Greene Chair for Distinguished Contributions to Education. Maxine has been the recipient of Honorary Degrees in the Humanities from ten universities including McGill University and has been awarded numerous honours including the American Educational Research Association's Lifetime Achievement Award and a Fulbright fellowship.

For several decades, Maxine has hosted a weekly series of literary Salons in her own home. The Salon concept has recently expanded to include music and theatrical performances. She continues to appear as a featured speaker and panelist at academic and cultural institutions throughout the United States and Europe, and has also appeared in the multimedia dance piece, The Hershey Man, produced by La Manga Video and Dance Company.

LINK TO:

www.maxinegreene.org 